\title{
MOLECULAR IDENTIFICATION AND GENETIC STUDIES IN PERUVIAN PHRAGMIPEDIUMS
}

\author{
Isaias Rolando ${ }^{1,3}$, M. RodrígueZ 1 , M. DAMIAN ${ }^{2}, J_{\text {J BenaVides }}^{1}$, \\ A. MANRIQUE ${ }^{2} \& \mathrm{~J}$. ESPINOZA ${ }^{1}$ \\ 'Universidad Peruana Cayetano Heredia, Av. Honorio Delgado 430, Lima 31, Peru \\ ${ }^{2}$ Centro de Jardinería Manrique y Universidad Nacional Agraria \\ ${ }^{3}$ Author for correspondence: orchid@upch.edu.pe
}

KeY Words: Phragmipedium, DNA markers, ITS sequences, AFLP sequences, Phragmipedium kovachii,

Phragmipedium boisserianum

Peru has inherited one of the greatest biodiversities of the planet. The orchid genus Phragmipedium has several representatives in the country. They are listed in Appendix 1 of CITES, restricted from international trade.

Molecular analyses can be used as database for legal and forensic determinations. Phylogenetic analyses distinguish species in the genus Phragmipedium with low sequence divergence within sections. DNA markers of Phragmipedium besseae, $P$. besseae var flavum, $P$. boisserianum, $P$. caricinum, $P$. caudatum, $P$. kovachii, $P$. longifolium, $P$. pearcei, $P$. schlimii and $P$. wallisii were studied.

As expected, the individual and combined analyses demonstrate the distinctiveness of the molecular sequence data of Phragmipedium kovachii. An elucidation of the systematic in sections Micropetalum and Schluckebieria is presented. Our results also propose a close phylogenetic relationship of Phragmipedium boisserianum to section Himantopetalum.

Dendograms with AFLP (nuclear ADN) technique and ITS (internal transcribed spacer of nuclear ribosome) techniques can contribute to establish the taxonomy of Phragmipedium kovachii related to other species.

A well vouchered database of species and hybrids of Phragmipediums is under construction to determine the illegal origin of plant material by using DNA sequence data. 